\title{
EKSPERYMENTALNE DOMY JEDNORODZINNE LAT 60' I 70’ XX WIEKU W POLSCE
}

\author{
Zuzanna Napieralska \\ Wydział Architektury Politechniki Wrocławskiej, \\ Faculty of Architecture, Technical University of Wrocław \\ e-mail: zuzanna.napieralska@pwr.wroc.pl
}

\begin{abstract}
Streszczenie: W artykule przedstawiono przykłady architektury eksperymentalnej w zakresie budownictwa jednorodzinnego na przełomie lat 60' i 70' XX w. Realizacje te były odpowiedzią na ograniczenia normatywne dotyczące powierzchni użytkowej domów jednorodzinnych, braki w dostępności materiałów budowlanych oraz potrzebę intensyfikacji zabudowy. Przedstawiono dwa przykłady realizacji domów kopułowych o różnej konstrukcji oraz dwa przykłady mini osiedli w zabudowie atrialnej.
\end{abstract}

Słowa klucze: dom jednorodzinny, domy kopułowe, zabudowa atrialna, zabudowa dywanowa, eksperymentalne budownictwo

\section{WSTĘP}

Ciekawe i oryginalne projekty domów jednorodzinnych przełomu lat '60 i '70 XX w. były wciąż rzadkością i jak napisał Z. Skrzydlewski w magazynie Architektura z 1974 r.: Doszło już właściwie do tego, że każdy udany egzemplarz tego budownictwa wywotuje bez mata sensację [9]. W tamtych latach w zabudowie jednorodzinnej mieściło się ponad 30\% ogólnej liczby ludności, jednak znaczna większość z tych budynków pochodziła z katalogów typowej zabudowy jednorodzinnej. Oznaczało to, w dużej mierze, standardową i stypizowaną architekturę, o niskich walorach estetycznych. Budownictwo komunalne musiało być tanie a co za tym idzie zunifikowane. Typizacja nigdy nie sprzyjała rozwijaniu indywidualnych dązeń artystycznych architektów [6].

Domy atrialne były przykładem eksperymentu urbanistycznego, który miał na celu maksymalne zintensyfikowanie zabudowy jednorodzinnej. Natomiast domy- kopuły były eksperymentem konstrukcyjnym oraz umożliwiały stworzenie większej powierzchni użytkowej niż to było dozwolone normatywem.

\section{DOMY KOPUŁOWE}

Wszechobecna stypizowana zabudowa jednorodzinna miała swoje wyjątki. Szczególnie w latach 60' ubiegłego wieku, w okresie małej stabilizacji, możliwe było kreowanie nowych form mieszkalnych. Eksperymentom budowlanym sprzyjał fakt, iż w tym czasie bardzo rozwinęły się technologie materiałowe i konstrukcyjne, umożliwiające tworzenie futurystycznych form. Pisał o tym Duszan Poniż, konstruktor Politechniki Warszawskiej: Odkrycia nauki wyciskaja piętno na wszelkich przejawach życia. (...) Wiedza i nauka otwiera przed naszym widzeniem, styszeniem, smakiem i dotykiem nowe możliwości [7]. Modne w tym okresie były kształty krzywolinijne, inspirowane formami organicznymi. Podkreślały one ergonomię form wywodzących się z natury. Niezwykle popularne na przełomie lat 50' i 60' obłe kształty dotarły do każdej dziedziny sztuki użytkowej. W architekturze te eksperymentalne formy znalazły swoje odzwierciedlenie w budynkach jednorodzinnych. Ich mała skala i stosunkowo niewielkie koszty realizacji pozwoliły na stworzenie kilku oryginalnych realizacji. Tak daleko idący eksperyment byłby utrudniony dla budynków wielorodzinnych czy usługowych. 
Jedną z ciekawszych realizacji wywodzących się z tego nurtu projektowego było warszawskie osiedle domków jednorodzinnych, tak zwanych kopulaków.

Autorem projektu był Andrzej Iwanicki, a sam projekt został zrealizowany w latach 1961-1966 przy ulicy Ustrzyckiej. Tereny pod budowę futurystycznych domów wykupiło Spółdzielcze Zrzeszenie Budowy Domów Jednorodzinnych Zakątek, od niego też pochodzi nazwa kolonii domków jednorodzinnych - Zakatek. W pierwotnych założeniach osiedle miało skupiać ponad siedemdziesiąt domów, jednak z powodów ekonomicznych, wiążących się głównie z brakami materiałowymi i rosnącymi kosztami, powstało jedynie dziesięć z nich.

W skład kolonii wchodziły podpiwniczone domy dwukopułowe oraz trzykopułowe. Same kopuły umożliwiały uzyskanie dodatkowej przestrzeń, ponad normatyw przyjęty dla domu jednorodzinnego. Było spowodowane to tym, że powierzchnia użytkowa mieszkania liczona była od wysokości $2,20 \mathrm{~m}$, natomiast pod łukami kopuł była ona niższa. Tym sposobem właściciel domu mógł uzyskać do $30,0 \mathrm{~m}^{2}$ nadprogramowej powierzchni.

Dom wbrew swojej oryginalnej formie był tani i łatwy w budowie. Powodem tego były powtarzalne elementy konstrukcyjne. Prawdopodobnie dostosowano do ich budowy prefabrykaty do konstrukcji silosów. Kopuły miały konstrukcję żelbetową, wykonaną z powtarzalnych czterdziestu prefabrykatów, które następnie zbrojono i zalewano betonem tworząc jednorodną łupinę o promieniu wewnętrznym $3,30 \mathrm{~m}$. Konstrukcja ta, u podstawy przechodziła w tambur o wysokości 50,0 cm. Kopuły ocieplano od zewnątrz plastrami pumeksu i tynkowano.

Wewnątrz jednej z kopuł mieścił się przestronny pokój dzienny o powierzchni prawie $35,0 \mathrm{~m}^{2}$, inne były podzielone ścianami wydzielając pomieszczenia sypialni, łazienek czy kuchni. Jednak centralną częścią budynku był sześciokątny element łączący dwie lub zwieńczony płaskim stropem. W nim projektowano jadalnię. Okna w budynku zaprojektowane były w formie wystających lunet, wylewanych osobno na dostawnych szalunkach skrzynkowych. Autor projektu zadbał również o projekt wnętrza. Problemowe i nieustawne pomieszczenia wymagały specjalnie zaprojektowanych systemów szaf i pawlaczy. Należy również zaznaczyć, że wszystkie instalacje w budynku, również musiały być dostosowane do obłych ścian.

Obecnie osiedle jest zapomniane a część budynków mocno zmieniona przez właścicieli domów. Nikt nic o niech nie wie, nie ma ich $w$ atlasach, $w$ przewodnikach ani $w$ książkach o architekturze. Gdyby stały kilkaset kilometrów na zachód, ich zdjęcia ilustrowatyby kolorowe pocztówki i foldery. Gdyby trafity $n p$. do Persji, statyby się ulubionymi typowymi domami. Niestety, Kopulaki stoją sobie spokojnie na ulicy Ustrzyckiej w Warszawie, nieodkryte od $1966 r$. [4]

Projekt budynków trzykopułowych został zastrzeżony w urzędzie patentowym i co za tym idzie nie zezwala się na ingerencję w jego formę. 


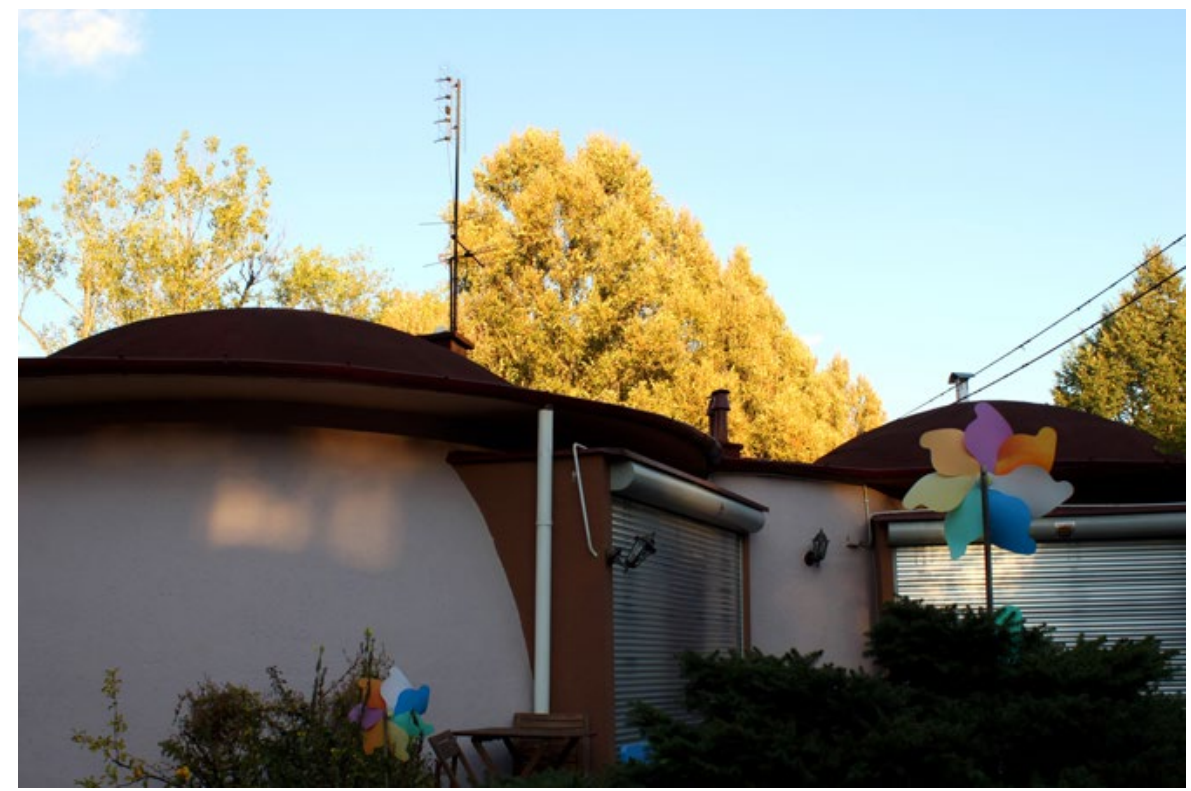

Ryc. 1. Domy Kopułowe przy ul. Ustrzyckiej w Warszawie, obecny stan (fot. Anna Łyszcz) Fig.1 The Dome Houses at Ustrzycka street in Warsaw, present condition (fot. Anna Łyszcz)

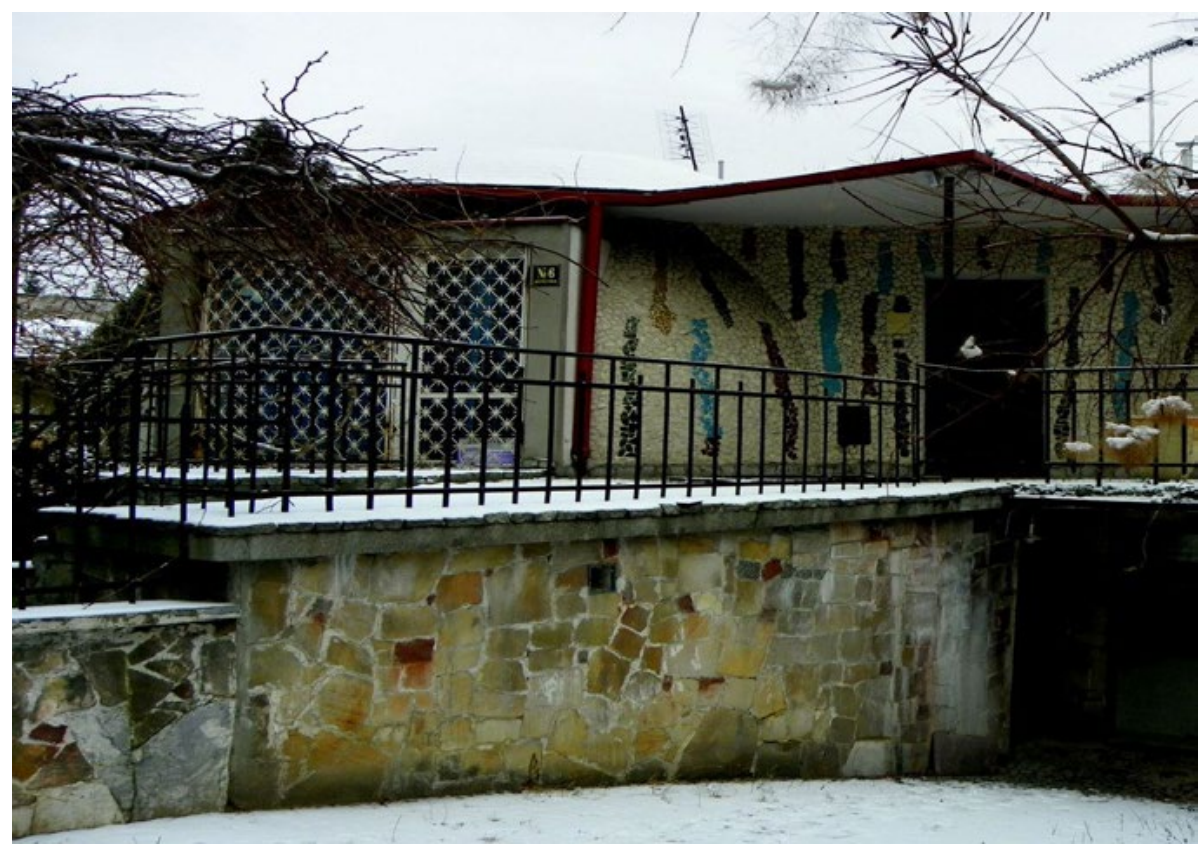

Ryc. 2. Domy Kopułowe przy ul. Ustrzyckiej w Warszawie, obecny stan (fot. blog: warszawy historia ukryta) Fig. 2. The Dome Houses at Ustrzycka street in Warsaw, present condition (fot. blog: warszawy historia ukryta) 


\section{DOM WŁASNY ARCHITEKTA WITOLDA LIPIŃSKIEGO}

Innym niezwykle innowatorskim, zrealizowanym projektem domu jednorodzinnego jest dom własny architekta Witolda Lipińskiego, potocznie nazywany Igloo. Znajduje się on we Wrocławiu w dzielnicy Zalesie, przy ulicy Moniuszki. Dom od początku istnienia, jeszcze na etapie budowy budził zainteresowanie. Dla samego twórcy był on również laboratorium badań ${ }^{1}$.

Projektant również zastosował przekrycie kopułowe nad budynkiem, jednak w tym wypadku konstrukcja jest murowana. Do stworzenia kopuły wykorzystał on cegłę rozbiórkową z okolicznych poniemieckich willi i samodzielnie ją wykonał używając do tego sztywnej drewnianej łaty, która miała dwa stopnie odgięcia i zakończona była półką do układania cegły. W przekroju skorupa domu igloo miała stały wymiar $12,0 \mathrm{~cm}$ od przyziemia po sklepienie. Budynek od wewnątrz został ocieplony innowatorską pianką formaldehydową (był to również element eksperymentu) spienianą na miejscu, w konsystencji przypominającą obecne pianki poliuretanowe, o grubości $7 \mathrm{~cm}$. Od zewnątrz powłoka została przekryta papą i blachą aluminiową. Obecnie budynek został ocieplony styropianem od zewnątrz a pokrycie z blachy zostało już kilkakrotnie wymieniane.

Eksperyment Lipińskiego miał na celu nie tylko spisywanie pomiarów parametrów mikroklimatycznych ale przede wszystkim był odpowiedzią na wymogi taniego budownictwa mieszkaniowego, obwarowanego normatywami powierzchniowymi. Kształt igloo zapewniał najmniejsze zużycie materiału do budowy ścian w stosunku do powierzchni. Ostatecznie ta oryginalna konstrukcja była o ok. 30\% tańsza od typowego budownictwa jednorodzinnego. Średnica kopuły ma $10 \mathrm{~m}$. i mieści w parterze trzy pokoje zlokalizowane po obwodzie oraz kuchnię i łazienkę, natomiast w części centralnej znajduje się pokój dzienny z kominkiem. Powierzchnia użytkowa parteru wynosi ok. $70 \mathrm{~m}^{2}$. Na trzydziestometrowej antresoli obecnie mieści się pokój gościnny, a dawniej była tam pracownia profesora Witolda Lipińskiego. W znacznej części została ona wykonana $\mathrm{z}$ ażurowej kratownicy przepuszczającej światło z dużego świetlika usytuowanego na szczycie kopuły. Dzięki zastosowaniu antresoli, której powierzchnia nie została wliczona do części użytkowej, architekt mógł starać się o kredytowanie budowy ${ }^{2}$. Podobnie jak w warszawskich domkach kopułowych tak w projekcie Lipińskiego do umeblowania przestrzeni wewnątrz Igloo wymagane było tworzenie mebli na zamówienie. Do półkolistego budynku dostawiony jest budynek garażu z pomieszczeniem gospodarczym w kształcie półwalca.

Profesor Lipiński wybudował we Wrocławiu jeszcze dwa inne domy jednorodzinne o powłokowych przykryciach. Budynek przy ul. Szramki we Wrocławiu, projektowany na zamówienie po sukcesie domu igloo, ma kształt półwalca o przekroju wyostrzonego łuku, jednak niejednakowego na całej długości walca. Ta przypadkowa, wydawałoby się, forma robi wrażenie organicznej. Również na zamówienie powstał bardziej zbliżony formą, do domu architekta, budynek przy ulicy Wyścigowej we Wrocławiu. W przypadku tej realizacji ciężko mówić o udanym eksperymencie. Ze względu na liczne zmiany projektowe wprowadzane przez inwestora na etapie budowy budynek odbiegał od pierwotnej wizji architekta i nie był przez niego uznany za satysfakcjonujący.

1 Witold Lipiński prowadził w domu różnego rodzaju pomiary: wilgotnościowe, temperatury czy przepływu powietrza aby badać energooszczędność budynku. Na podstawie swoich badań napisał pracę habilitacyjną.

2 Pożyczka od państwa przyznawana była dla domów nieprzekraczających $75 \mathrm{~m}^{2}$ powierzchni użytkowej. 


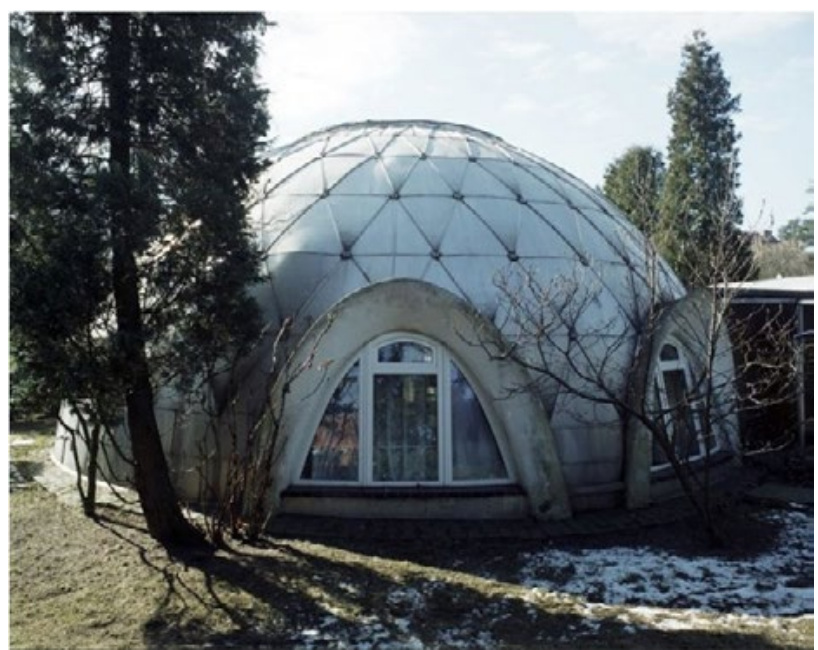

Ryc. 3. Dom Igloo architekta W. Lipińskiego przy ul. Moniuszki we Wrocławiu (fot. Filip Springer) Fig. 3. The Igloo House of an architekt W. Lipiński at Moniuszki street in Wrocław (fot. Filip Springer)
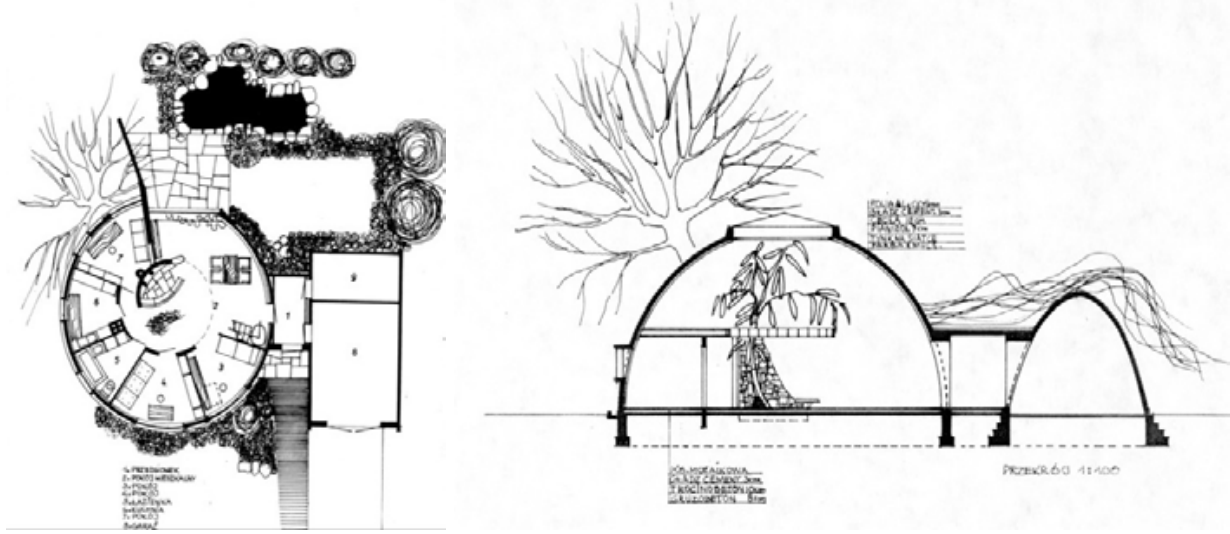

Ryc. 4. Rzut i przekrój domu Igloo we Wrocławiu (fot. Miłosz Lipiński)

Fig.4. A plan and section of the Igloo House in Wrocław (fot. Miłosz Lipiński)

\section{ZABUDOWA ATRIALNA}

Intensywna, dywanowa zabudowa jednorodzinna pozwala na lepsze wykorzystanie przestrzeni na drogich, miejskich działkach oraz umożliwia tańszą realizację otaczającej infrastruktury drogowej oraz uzbrojenie działek. Duże zainteresowanie tego typu budownictwem nastąpiło w latach 70' ubiegłego wieku. Wynikało to z 'poluzowania' norm budowlanych i wcześniejszego, silnego nacisku na realizację małych typowych domków katalogowych. W latach 70' projektowano małe osiedla jednorodzinne, a zabudowa dywanowa najlepiej sprzyjała ekonomicznym założeniom projektowym (...) dawała możliwość zróżnicowanego ksztaltowania przestrzeni osiedla. (...) Jest to forma zabudowy, która najlepiej odpowiada potrzebom psychiki ludzkiej, ze względu na bezpośrednie powiazanie ze środowiskiem naturalnym [2]. Umożliwiała także nawiązywanie lepszych relacji między mieszkańcami i ich identyfikację z otoczeniem. 
Jednym z przykładów tego typu budownictwa był Zespół Domów Atrialnych w Warszawie przy ul. Orężnej, który zdobył nagrodę Ministra Gospodarki Terenowej i Ochrony Środowiska w 1974 r. Projekt ten został doceniony ze względu na czytelny rzut z elastycznym układem funkcjonalnym, umożliwiającym dostosowanie budynku do potrzeb użytkowników, oraz samą estetykę bryły, elewacji i otocznia, gdzie dopracowane były wszystkie detale.

Zespół domów atrialnych został zaprojektowany i zrealizowany całkowicie zgodnie z założeniem zespołu architektów pod kierunkiem Donata Putkowskiego, co w tamtym okresie, ze względu na braki materiałowe, finansowe i prawne było utrudnione. Jednak nie tylko to było sukcesem osiedla. W tekście Spetnione życzenia Zygmunt Skrzydlewski pisze: Przyznana nagroda jest również poparciem działania wskazującego możliwości innego niż dotychczas podejścia do tematu [9]. Wnętrze każdego budynku, wchodzącego w skład kolonii domów, zostało zaprojektowane przez innego architekta. Projekt zakładał stworzenie 12 parterowych, niepodpiwniczonych domków. Na działce o powierzchni 0,46 ha usytuowano pięć par domów z wspólnym atrium i dwa domy półotwarte. Wszystkie budynki zostały zaprojektowane na planie litery L. Powierzchnia działki poszczególnych domów wahała się od 158,0 do $380,0 \mathrm{~m}^{2}$, powierzchnia użytkowa od 80,0-126,0 $\mathrm{m}^{2}$ a powierzchnia atriów od 48,0 do $130,0 \mathrm{~m}^{2}$.

Ze względu na trudny do zagospodarowania kształt działki, budynki zostały usytuowane uskokowo. Cofnięcia kolejnych segmentów zaaranżowano na zieloną strefę wejścia a także miejsce na wkomponowany w ogrodzenie, obudowany śmietnik.

W krótszym skrzydle budynków, prostopadłym do wejść, umieszczono część dzienną z kuchnią, natomiast sypialnie oraz łazienkę w skrzydle równoległym, o długości 7,0 m.

Ściany zewnętrzne domów oraz wnętrz atriów wykonane zostały z jasnej, nieotynkowanej cegły, dodając prostej formie budynków szlachetności. Cegła była elementem łączącym wszystkie segmenty. Aranżacje atriów, ilość i wielkość otworów okiennych czy układ ścian wewnętrznych były projektowane indywidualnie. Nie wpłynęło to jednak na fakt, że kolonia domów atrialnych tworzyła spójną całość.

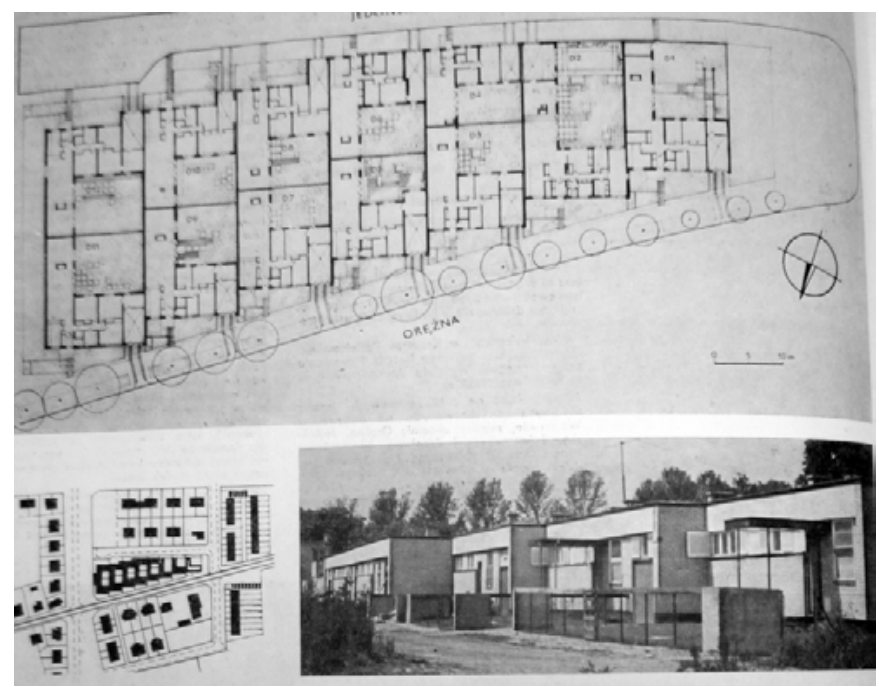

Ryc. 5. Rzut i sytuacja zespołu domów atrialnych w Warszawie przy ul. Orężnej (fot. Architektura 5 '74)

Fig. 5. The plan and situation of a complex of the single-family atrial houses in Warsaw at Orężna street (fot. Architektura 5 '74) 


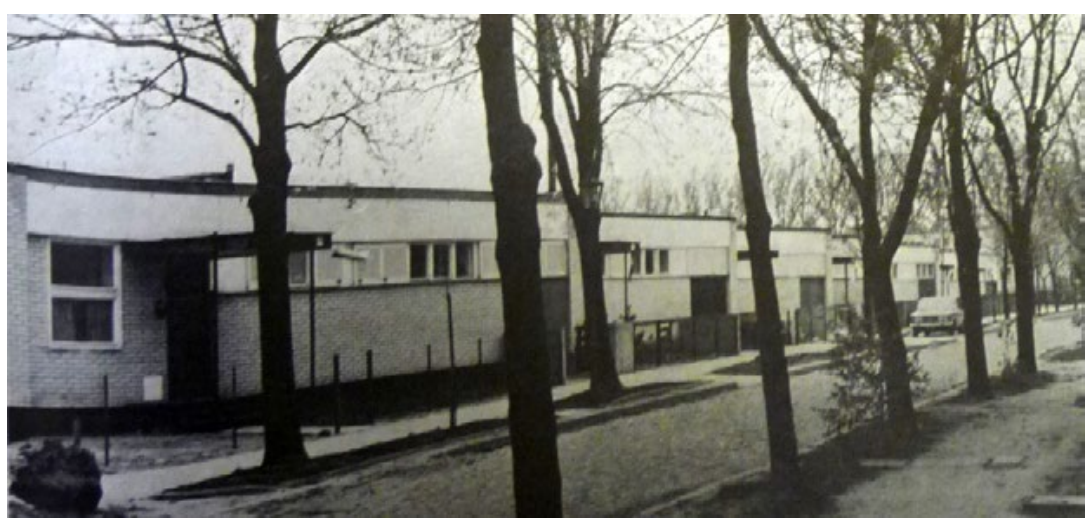

Ryc. 6. Kompleks domów atrialnych przy ul. Orężnej w Warszawie (fot. Architektura 5 '74) Ryc.6. A complex of the single-family atrial houses in Warsaw at Orężna street (fot. Architektura 5 '74)

Innym przykładem realizacji domów jednorodzinnych w zabudowie atrialnej był zespół domów jednorodzinnych Patronat w Warszawie. Autorem projektu był zespół projektowy pod kierunkiem Andrzeja Haintze. Osiedle powstało na terenie przeznaczonym pod budowę typowych, wolno stojących budynków jednorodzinnych. Projektant zaproponował jednak zintensyfikowanie zabudowy, kosztem zmniejszenia ilości zieleni przydomowej, tworząc osiedle dziewiętnastu domów, zamiast planowanych wcześniej sześciu kostek.

Budynki zaprojektowane zostały w taki sposób aby na dwa segmenty przypadało jedno atrium. Użytkownicy domu, na działce o powierzchni od 220,0 do $270,0 \mathrm{~m}^{2}$, mieli do dyspozycji atrium oraz niewielki przedogródek. Tak niewielka ilość zieleni przypadająca na segment była zamierzeniem projektanta: Jestem przeciwnikiem traktowania zieleni na dziatce jako otoczki domu lokowanego pośrodku. Niezabudowany teren stanowi bowiem wówczas stracona powierzchnię o blizej niesprecyzowanej funkcji [1]. Według architekta atrium było wystarczającą przestrzenią zieloną, dodatkowo było ono przedłużeniem pokoju dziennego. W osiedlu wydzielić można było trzy typu domów: trzypokojowe, o powierzchni $100,0 \mathrm{~m}^{2}$, pięciopokojowe o powierzchni $115,0 \mathrm{~m}^{2}$ oraz mieszkania jednoprzestrzenne, mieszczące różne funkcje w jednej otwartej przestrzeni o powierzchni - 100,0 m². Część z segmentów miała dodatkowo garaż, wszystkie były podpiwniczone.

Założeniem projektantów było, aby stworzone warianty można było dostosowywać do indywidualnych potrzeb. Było to nowatorskie podejście, biorąc pod uwagę wszechobecne typowe i powtarzalne domy. Architekci zrobili ukłon w stronę potrzeb przyszłego mieszkańca osiedla. Zaletą projektowanego osiedla była możliwość dobrego doświetlenia wszystkich pomieszczeń, przy jednoczesnym wprowadzeniu ślepych ścian od strony atrium sąsiada. Stwarzało to wrażenie intymnej i wyizolowanej przestrzeni. Układ funkcjonalny w każdym segmencie został tak zaprojektowany aby wszystkie pomieszczenia miały kontakt wizualny z podwórkiem.

Kolonia domów atrialnych została zaprojektowana i wybudowana przez przyszłych jej mieszkańców. Był to, według projektanta, ciekawy eksperyment. Zorganizowanie takiej samowystarczalnej grupy' wpłynęło na koszty budowy i ponieważ każdy budował dla siebie, dbał o jakość wykonania pracy. Budowa osiedla trwała przez trzy lata, a każdy ze współmieszkańców przepracował na niej 3500 godzin. Przydziały domów nastąpiły dopiero po zakończeniu budowy, według wkładu pracy i inwencji kolejnych osób: sporzadziliśmy liste wedtug wktadu pracy i inicjatywy każdego z 'budowniczych'. Pierwszy z tej listy wybierat sobie domek spośród dziewiętnastu w osiedlu, drugi-z pozostałych osiemnastu itd. [1].

Budynki zostały wzniesiony w technologii murowanej z bloczków suporeksowych, pochodzących częściowo z rozbiórek lub jako niepełnowartościowe materiały. Stropodachy 
wykonane zostały z belek T-27 ocieplonych wełną mineralną i z racji niewielkich rozpiętości możliwe było ich ręczne układanie, bez wprowadzania ciężkiego sprzętu. Cały projekt zakładał możliwość realizacji za pomocą rąk własnych i lekkiego sprzętu, co było atrakcyjne. Wynajem koparek czy małego dźwigu był niezwykle trudny.

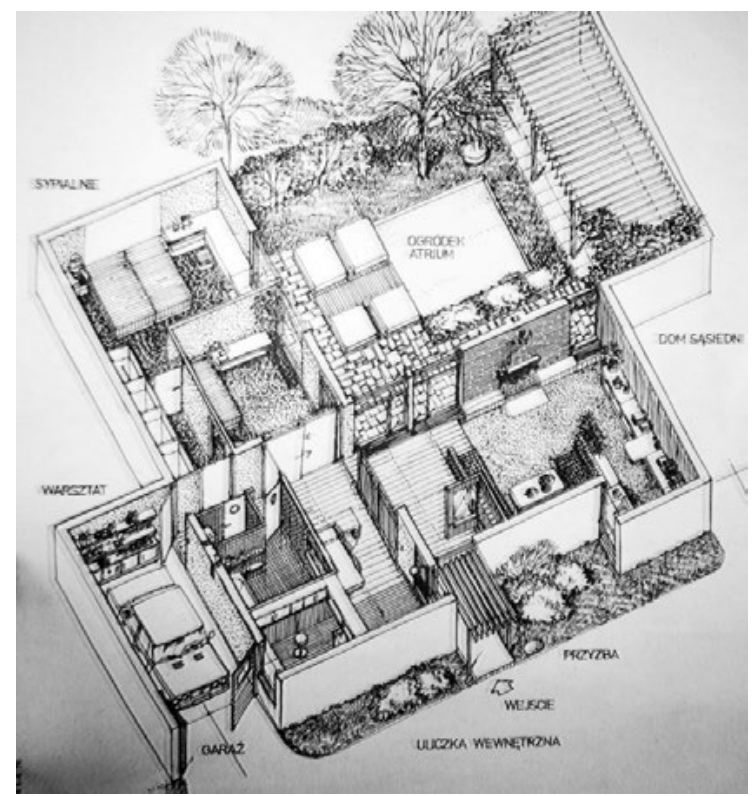

Ryc. 7. Aksonometria jednego z domów atrialnych przy ul. Żółkiewskiego w Warszawie (rys. Architektura 5-6 '78) Fig. 7. An axonometry of one of the atrial house from Żółkiewskiego street in Warsaw (rys. Architektura 5-6 ’78)

\section{PODSUMOWANIE}

Normy ograniczające parametry domu, brak materiałów budowlanych, utrudnienia przy kredytowaniu i wiele innych przeszkód na drodze do realizacji własnego domu, wbrew pozorom bywały także bodźcem dla kreatywnego myślenia. Wszelkie ograniczenia zmuszały do poszukiwania nowych rozwiązań. Człowiek zawsze szukał najprostszych sposobów do realizacji swojego celu. Jednak bardziej rozwojowe podejście do każdego tematu wymaga pewnych ram, które go ograniczają. Eksperymenty budowlane mogłyby nie powstać i nie zrealizowano by tak fascynujących budynków mieszkalnych.

Niestety obecnie, przedstawione powyżej obiekty nie są traktowane z należytym szacunkiem. Część z nich, jak na przykład kolonia domków kopułowych jest zupełnie odmieniona. Część z nich została bezpowrotnie przebudowana, natomiast inne po termomodernizacjach zmieniły swój charakter. Współcześnie nie buduję się w Polsce jednorodzinnej zabudowy dywanowej, lub jest ona niezwykle rzadka. Ważne więc, aby zrealizowane w tym systemie mini osiedla otoczyć opieką konserwatorską i ograniczyć ingerencje w ich kształt. To samo powinno dotyczyć innych eksperymentalnych budynków realizowanych w PRL-u. 


\title{
PIŚMIENNICTWO
}

Architektura 5-6, 1978, wywiad z architektem Andrzejem Haintze, s. 93-94.

Architektura 7-8'78, s. 87.

Giergoń P., Warszawa - domki kopułowe na Okęciu, www.sztuka.net

Kucewicz M., 2004, Kopulaki, Fluid 5 (42.

Łyszcz A., Kopulaki, ul. Ustrzycka, www.powojennymodernizm.com.

Pokrzywicka K., 2003, Kontrasty, metamorfozy, styl - czyli rozważania o dynamice przemian architektury XX wieku, s. 53, Politechnika Gdańska

Poniż D., Projekt 1960, nr 1-2, Krajobrazy współczesności. Uwagi na marginesie książki Gyorgy Kenesa,s. 34-37.

Przesmycka E., 2013, Willa Lipińskich, [w:] Słynne wille Polski, pod red. R. Nakonieczny, FOIBOS, BOHEMIA Praga, s.246-249.

Skrzydlewski Z., Architektura 5 '74, Spetnione życzenia, s. 56.

Springer F., 2011, Źle urodzone - reportaże o architekturze PRL-u, Karakter.

Szafer P., 1977, Polska architektura wspótczesna, Interpress Warszawa.

\section{EXPERIMENTAL SINGLE FAMILY HOUSES FROM THE 60’ AND 70' OF 20TH CENTURY IN POLAND}

\begin{abstract}
The article presents examples of the experimental architecture in the field of single-family housing construction. The time period of the research are 60 'and 70' of 20th century. Presented projects were a response to the normative limitations of usable area in standard houses, luck of material supplies and the need for intensification of that building. The article presents two realized dome houses, build in different construction system and two types of atrial houses - as the examples of dense housing urbanism.
\end{abstract}

Key words: single family house, atrial housing, dome house, experimental architecture, 